minary explorations of firms$-62$.

lence of industry structure or lance for high potential indeing, 14(2), 165-87.

iscent and fledgling entreprerocess', Entrepreneurship and

! Denmark 2006 - studied via sity of Southern Denmark.

king for Entrepreneurship in 'enmark.

en networking and firm per$2-74$.

l), 'The internationalization iurnal of Business Venturing, zcess of start-ups', Entrepre-

\title{
7. Structuring the field of social entrepreneurship: a transatlantic comparative approach ${ }^{1}$
}

\author{
Sophie Bacq and Frank Janssen
}

\section{INTRODUCTION}

During recent years, social entrepreneurship has been receiving greater recognition from the public sector, as well as from scholars (Stryjan, 2006; Weerawardena and Sullivan Mort, 2006). Encouraging social initiatives has been on our governments' agenda for a while. European policy makers claim the importance of social enterprises as 'they not only are significant economic actors, but also play a key role in involving citizens more fully in Society and in the creation and reproduction of social capital, by organizing, for example, opportunities for volunteering' (European Commission, 2003). Consequently, several European states have created specific legal forms for this kind of initiatives. On the other hand, famous business schools all around the world have created centres for research and education programmes in social entrepreneurship. So far, academic research in social entrepreneurship "has largely been focused on defining what it is and what it does, and does not, have in common with commercial entrepreneurship' (Nicholls, 2008: 7).

No doubt that this growing interest toward social entrepreneurship partly results from its innovativeness in treating social problems that are becoming more and more complex (Johnson, 2000; Thompson et al., 2000). Some academic scholars see it as a way of creating community wealth (Wallace, 1999) while others consider it as a means to relieve our modern society from its illnesses (Thompson et al., 2000), such as unemployment, inequalities in the access to health care and social services (Catford, 1998), squalor, poverty, crime, privation or social exclusion (Blackburn and Ram, 2006). It can also be considered as a means to subcontract public services or as a means to improve these services without increasing the state's intervention (Cornelius et al., 2007). Moreover, this innovative entrepreneurial practice bears the advantage of blurring 
traditional boundaries between private and public sectors, giving birth to hybrid enterprises (Johnson, 2000; Wallace, 1999) guided by strategies of double value creation - social and economic (Alter, 2004).

A consensus has thus emerged according to which understanding social entrepreneurship is important (Weerawardena and Sullivan Mort, 2006; Dees, 1998a). However, this concept has long remained poorly defined and its boundaries with other fields of study remained fuzzy (Mair and Martí, 2006). Therefore, this chapter has three objectives. The first objective is to clarify the three main concepts of the field: 'social entrepreneurship' (seen as a process), 'social entrepreneur' (as an individual) and 'social enterprise' (as an organization), since these three notions have been used interchangeably to express the same idea. To that end, we will review the literature from an analytical and critical perspective. The second objective of this chapter is to determine to what extent these concepts differ from traditional or commercial entrepreneurship/entrepreneur/enterprise. If an organization devotes part of its income to a social cause, we cannot necessarily speak of social entrepreneurship. The same holds for all nonprofit organizations that adopt managerial practices (Mair and Martí, 2004). Therefore, a person who is in charge of the management of an organization that acts in the social, voluntary or community fields will rather be called 'social enterprise manager' because a social entrepreneur has to meet the entrepreneurial condition (Brouard, 2007). Finally, several approaches of social entrepreneurship seem to emerge. Their differences could be due to their geographical origin. Because Europe and the United States consider the government's role from different perspectives, we assume that both sides of the Atlantic consider the role of social entrepreneurship differently. Consequently, we presuppose that each side focuses on particular elements, such as the individual features or the collective aspects of the initiative. Therefore, the third objective of this chapter is to identify the different schools of thought and practices on both sides of the Atlantic and to determine whether there is a transatlantic divide in the way of approaching social entrepreneurship.

This chapter is organized as follows. The first section presents the practical and academic background of social entrepreneurship as a field of research. In the second section, our method for reviewing the literature is explained. The third section of this chapter presents and discusses the results of our literature review. Finally, the fourth section examines whether there is a transatlantic divide in the way of approaching and defining social entrepreneurship, the social entrepreneur and the social enterprise.

In the next section, we show how social entrepreneurship can learn from the development of entrepreneurship as a legitimate field of research.

\section{FROM SOCI A PRACTICI RESEARCH}

Social entrepreneursh around the world ${ }^{2}$ (F entrepreneurship as a a long heritage and a attention for a few ye research on the topic Light, 2005), the term world, in the late 1990 al., 2000; Bornstein, 1 Kingdom (SSE, 2002 have begun to attract enterprise' appeared 2001). Since the midused in Europe, espe network, namely EM

From an academic that the emerging fiel similarities with the First, social entrepre and Martí, 2006). As social entrepreneursk ers before attracting (2001) and Shane an lack of a unifying par article, "What are we Gartner (1988) tackl become a label of co preneurship just a b that can be identifie Audretsch's (2003) distinctive field of $\mathrm{rc}$ moderated this lack ing the definition of the paradigm. Indee remains one of the $r$ disciplines. Consequ of their own discip Similarly, one can $r$ 
te and public sectors, giving birth to allace, 1999) guided by strategies of nomic (Alter, 2004).

rding to which understanding social awardena and Sullivan Mort, 2006; as long remained poorly defined and dy remained fuzzy (Mair and Martí, ree objectives. The first objective is "the field: 'social entrepreneurship' teur' (as an individual) and 'social these three notions have been used dea. To that end, we will review the al perspective. The second objective at extent these concepts differ from leurship/entrepreneur/enterprise. If come to a social cause, we cannot urship. The same holds for all nonagerial practices (Mair and Martí, charge of the management of an voluntary or community fields will ager' because a social entrepreneur on (Brouard, 2007). Finally, several seem to emerge. Their differences sin. Because Europe and the United le from different perspectives, we consider the role of social entrepre2 presuppose that each side focuses adividual features or the collective third objective of this chapter is to it and practices on both sides of the 'e is a transatlantic divide in the way .

ws. The first section presents the $f$ social entrepreneurship as a field Ir method for reviewing the literathis chapter presents and discusses inally, the fourth section examines $e$ in the way of approaching and social entrepreneur and the social

ial entrepreneurship can learn from $s$ a legitimate field of research.

\section{FROM SOCIAL ENTREPRENEURSHIP AS A PRACTICE TO A LEGITIMATE FIELD OF RESEARCH}

Social entrepreneurship practitioners have always existed, everywhere around the world ${ }^{2}$ (Roberts and Woods, 2005). Nevertheless, if social entrepreneurship as a practice is far from being new and benefits from a long heritage and a global presence, it has been attracting researchers' attention for a few years only (Dearlove, 2004). Apart from isolated early research on the topic (Waddock and Post, 1991 and Young, 1986, cited in Light, 2005), the term 'social entrepreneurship' emerged, in the academic world, in the late 1990s in the United States (Drayton, 2002; Thompson et al., 2000; Bornstein, 1998; Dees, 1998a; Boschee, 1995) and in the United Kingdom (SSE, 2002; Leadbeater, 1997). In Europe, social enterprises have begun to attract our governments' attention. The concept of 'social enterprise' appeared for the first time in the late 1980s in Italy (Defourny, 2001). Since the mid-1990s, this concept has been more and more widely used in Europe, especially thanks to the works of a European research network, namely EMES. ${ }^{3}$

From an academic point of view, numerous authors agree on the fact that the emerging field of research in social entrepreneurship shows three similarities with the field of entrepreneurship research in its early days. First, social entrepreneurship research is still phenomenon-driven (Mair and Martí, 2006). As has been the case for the field of entrepreneurship, social entrepreneurship initiatives have first developed among practioners before attracting researchers' attention. Second, Bruyat and Julien (2001) and Shane and Venkataraman (2000), among others, regretted the lack of a unifying paradigm in the field of entrepreneurship. In his seminal article, 'What are we talking about when we talk about entrepreneurship?', Gartner (1988) tackled important questions such as 'has entrepreneurship become a label of convenience with little inherent meaning?' or 'is entrepreneurship just a buzzword, or does it have particular characteristics that can be identified and studied?'. This fuzziness brought up Acs and Audretsch's (2003) question of whether entrepreneurship constitutes a distinctive field of research or a discipline-based research. Filion (1997) moderated this lack of consensus in the field of entrepreneurship regarding the definition of the entrepreneur and the parameters that constitute the paradigm. Indeed, from the reverse point of view, entrepreneurship remains one of the rare topics that attract specialists from a lot of diverse disciplines. Consequently, any researcher is influenced by the premises of their own discipline in considering and defining the entrepreneur. Similarly, one can regret that the absence of a unifying paradigm in the 
field of social entrepreneurship has led to the proliferation of definitions (Dees, 1998a). 'Is social entrepreneurship a distinctive field of research?', Mair and Martí (2006) ask, or is it based on other disciplines? According to Dees and Battle Anderson (2006), attracting the interest of researchers from other disciplines will be both a source of legitimacy and of new knowledge. Let us stress that interdisciplinarity played a key role in the evolution of entrepreneurship, coming from a marginal field of research to a respected one (Dees and Battle Anderson, 2006). Third, academic research in social entrepreneurship is still at the infancy stage (Dees and Battle Anderson, 2006; Dorado, 2006), as the entrepreneurship field was some years ago (Brazael and Herbert, 1999). Entrepreneurship within the field of management sciences had then been characterized as a preparadigmatic field (Verstraete and Fayolle, 2004). Social entrepreneurship does not currently bear the explanatory or prescriptive theories that characterize a more mature field of research (Dees and Battle Anderson, 2006).

One can conclude that social entrepreneurship, considered as a subtheme of entrepreneurship, shows the same weaknesses as the latter at its beginning. That leads us to think that research in the field of social entrepreneurship could replicate the theoretical evolution of its parentfield, entrepreneurship. Therefore, even if the field of entrepreneurship has suffered from the lack of a federating paradigm, research has progressed and, today, some paradigms exist. Entrepreneurship is now recognized as an academic field (Bruyat and Julien, 2001) and has an important scientific community that has produced a significant body of research (Acs and Audretsch, 2003; McGrath, 2003). Indeed, the entrepreneurship field has managed to go beyond the infancy stage to reach the adolescence stage.

However, one could push the argument further and consider entrepreneurship as a sub-field of social entrepreneurship. Verstraete and Fayolle (2004) suggested that four paradigms can be used to delimit the field of entrepreneurship: the paradigm of business opportunity, the paradigm of venture creation, the paradigm of innovation and the paradigm of value creation. If we focus on the last one, it imports to discuss the definition of value. The value created by the entrepreneurial act is more than monetary since almost all ventures create at least some social value. A simple example is that any entrepreneurial process is at the source of job creation even if it is only the entrepreneur's job. Given this definition, entrepreneurship could be considered as being social by essence.

To progress in a new field of research, a clear definition is one of the key issues (Christie and Honig, 2006). As mentioned above, social entrepreneurship, as a very complex idea that carries around a wide range of beliefs and different meanings attached to it, lacks an agreed-upon definition. Therefore, an in-depth analysis of the literature could be useful to identify convergences, as we neurship. The next $\mathrm{s}$ literature review.

\section{LITERATU}

Given the various $b$ scholars in their stud topic have begun to instance, Zahra et al the complexity ind studying the subject nomenon. Their am 1 passes all the dimens the common points 'social entrepreneur taken to discover, social wealth by cres in an innovative ma

However, this ch the two classificatio review on social er used by Brush et al. able in entrepreneu in the entrepreneurs geographical origin understanding of so social value creatior

First, let us look that have emerged a presents them.

\subsection{The Geograph}

Attempts to under cally concentrated publications has be American scholars social entrepreneur divide between Eur Third Sector tradit 
1 to the proliferation of definitions hip a distinctive field of research?', ied on other disciplines? According attracting the interest of researcha source of legitimacy and of new ciplinarity played a key role in the ; from a marginal field of research Anderson, 2006). Third, academic still at the infancy stage (Dees and , as the entrepreneurship field was t, 1999). Entrepreneurship within then been characterized as a preolle, 2004). Social entrepreneurship $y$ or prescriptive theories that char(Dees and Battle Anderson, 2006). preneurship, considered as a subsame weaknesses as the latter at that research in the field of social heoretical evolution of its parentif the field of entrepreneurship has paradigm, research has progressed cepreneurship is now recognized as 2001) and has an important scienmificant body of research (Acs and eed, the entrepreneurship field has e to reach the adolescence stage. ent further and consider entrepreceneurship. Verstraete and Fayolle can be used to delimit the field of siness opportunity, the paradigm innovation and the paradigm of ne, it imports to discuss the definia entrepreneurial act is more than eate at least some social value. A rial process is at the source of job neur's job. Given this definition, s being social by essence.

, a clear definition is one of the key mentioned above, social entreprerries around a wide range of beliefs lacks an agreed-upon definition. terature could be useful to identify convergences, as well as divergences, in publications on social entrepreneurship. The next section presents the criteria we used to conduct such a literature review.

\section{LITERATURE REVIEW CRITERIA}

Given the various backgrounds and the numerous perspectives used by scholars in their study of social entrepreneurship, literature reviews on the topic have begun to flourish in academic journals and book chapters. For instance, Zahra et al. (2009) recently defined the concept. Acknowledging the complexity induced by the 'breadth of the scholarly communities studying the subject', they listed 20 definitions or descriptions of the phenomenon. Their ambition was not to end up with a statement that encompasses all the dimensions covered in the different approaches but to gather the common points of view. Zahra et al. (2009: 522) therefore suggest that 'social entrepreneurship encompasses the activities and processes undertaken to discover, define, and exploit opportunities in order to enhance social wealth by creating new ventures or managing existing organizations in an innovative manner'.

However, this chapter distinguishes itself from those pieces of work by the two classification criteria we used in order to systematize our literature review on social entrepreneurship. Indeed, following the methodology used by Brush et al. (2008) in their literature review of the outcome variable in entrepreneurship research, we classified research by main themes in the entrepreneurship literature, and looked at the differences in these by geographical origin of the publication. By doing so, we try to deepen the understanding of social entrepreneurship by distinguishing the process of social value creation from the individual or the organization.

First, let us look at the different approaches of social entrepreneurship that have emerged according to their geographical origin. The next section presents them.

\subsection{The Geographical Criterion}

Attempts to understand social entrepreneurship have been geographically concentrated on both sides of the Atlantic. In Europe the focus of publications has been more on social enterprises and legal forms, whereas American scholars have restricted their study of social entrepreneurship to social entrepreneurs and non-profits' ways of funding. This geographical divide between Europe and the United States can be explained by different Third Sector traditions. Indeed, from a European perspective, the Third 
Sector can be viewed as the private, not-for-profit ${ }^{4}$ sector and encompasses a large variety of organizations that generally include cooperatives and related enterprises, mutual societies as well as voluntary associations (Defourny and Nyssens, 2008). On the other hand, the American view of the Third Sector is restricted to the associative, non-profit world, that is all organizations that impose a strict prohibition of profit distribution to all persons who own or work in the organization. All profits must be reinvested in the organization's social purpose. Hence, cooperatives, in the heart of the European conception of social entrepreneurship, are excluded from the American perspective, as they do distribute profit - even in a limited way.

More precisely, two independent streams of thought have investigated the nature of social entrepreneurship in the United States, according to Dees and Battle Anderson's (2006) typology. Both schools have emerged in their own particular context and focus on particular aspects of social entrepreneurship. ${ }^{5}$ The American Social Innovation School of thought focuses on the establishment of new and better means to tackle social problems or to satisfy social needs. Although many people contributed to the birth of the Social Innovation School, one person and his organization were its driving force: Bill Drayton and Ashoka (Dees and Battle Anderson, 2006). Ashoka was created in 1980 in order to search and bring support to outstanding individuals with ideas for social change. Nevertheless, the term 'social entrepreneur' was not used before the mid1990 s as a substitute for the expressions 'innovator for the public sector' or 'public entrepreneur' which were used before. Since then, many other organizations supporting social entrepreneurs have appeared. ${ }^{6}$ These organizations also promote the development of social entrepreneurs' networks and build structures facilitating their access to funds. On the other hand, the American Social Enterprise School of thought focuses on income generation in conducting a social mission. Among the pioneering initiatives of this movement, New Ventures, a consultancy company specialized in the Third Sector, was founded in 1980. The growing interest of non-profit organizations for new financial sources - the traditional ones being grants and subsidies - motivated its creation. Other important initiatives emerged with the aim of professionalizing social enterprises through sharing best practices.

In Europe all approaches gather around the Third Sector and 'social enterprises' even though some national differences remain in terms of field of activities, statutes or modes of governance of social enterprises. Two types of definitions have been established. On the one hand, conceptual definitions have been given by international organizations, such as the OECD and the EMES Network, among others. On the other hand, legal definitions have been lish clear norms. Conc rooted in a specific na Moreover, the EMES taking the different $\mathrm{Et}$ this last perspective in spectives. From a then from the classical liter: the criteria relative to

\subsection{The Thematic $\mathrm{Cr}$}

First, Peredo and Mc. entrepreneurship is 10 in the sense that entr become entrepreneur: vidual and consists in ars, in the way they w in social entrepreneu 1982), some scholars social initiative, as w preneurship field of ship solely in terms whereas, according to right one to ask. The be a way of differenti social initiatives (Dee

Second, two dyn entrepreneurship, rel entrepreneurship. Th social entrepreneuria the approaches of so intensity of the social sity of the link betwe the entrepreneurial in

Third, following a ers became intereste neurship. From our regarding the social the legal form of the limitation or not of Other dimensions 
rofit ${ }^{4}$ sector and encomrally include cooperatives as voluntary associations land, the American view ve, non-profit world, that tion of profit distribution ation. All profits must be Ience, cooperatives, in the preneurship, are excluded tribute profit - even in a

hought have investigated ited States, according to th schools have emerged articular aspects of social ation School of thought ir means to tackle social many people contributed te person and his organiAshoka (Dees and Battle in order to search and ideas for social change. not used before the miditor for the public sector' Since then, many other have appeared. ${ }^{6}$ These of social entrepreneurs' access to funds. On the ool of thought focuses on ion. Among the pioneer, a consultancy company 1980. The growing intersources - the traditional reation. Other important alizing social enterprises

Third Sector and 'social ss remain in terms of field if social enterprises. Two the one hand, conceptual ganizations, such as the On the other hand, legal definitions have been set up by national governments in order to establish clear norms. Conceptual definitions bear the advantage of not being rooted in a specific national legislation and, therefore, are more neutral. Moreover, the EMES Network's broad approach bears the advantage of taking the different European national realities into account. We will use this last perspective in our comparison of the European and American perspectives. From a thematic point of view, three main themes have emerged from the classical literature on entrepreneurship. The next section discusses the criteria relative to the individual, the process and the organization.

\subsection{The Thematic Criterion}

First, Peredo and McLean (2006) make the hypothesis that defining social entrepreneurship is logically linked to the definition of the entrepreneur in the sense that entrepreneurship is 'what entrepreneurs do when they become entrepreneurs'. Therefore, our first criterion focuses on the individual and consists in identifying similarities and differences among scholars, in the way they weight the importance of the social entrepreneur's role in social entrepreneurship. Following an indicative approach (Casson, 1982), some scholars focused on the motivations of the founder of the social initiative, as well as on his/her particular features. As in the entrepreneurship field of research, these scholars have defined entrepreneurship solely in terms of 'Who the entrepreneur is' (Venkataraman, 1997) whereas, according to Gartner (1988), this question is not necessarily the right one to ask. The question of 'how does the entrepreneur act?' could be a way of differentiating the social entrepreneurial initiatives from other social initiatives (Dees, 1998b).

Second, two dynamic dimensions emerged from the literature on entrepreneurship, related to what Gartner (1988) called the 'process' of entrepreneurship. The first dimension refers to the goal at the basis of the social entrepreneurial creation. Convergences and divergences between the approaches of social entrepreneurship are measured here in terms of intensity of the social mission. The second issue regards the required intensity of the link between the social mission and the productive activities of the entrepreneurial initiative.

Third, following a functional approach (Casson, 1982), some researchers became interested in the organizational aspect of social entrepreneurship. From our literature review, three main dimensions emerged regarding the social enterprise: the centrality of the concept of 'enterprise'; the legal form of the social enterprise; and, linked to this dimension, the limitation or not of profit distribution.

Other dimensions could be found in the literature. By instance, numerous 
scholars (Gartner, 1985; Miller and Friesen, 1982) found that the environment was an important variable to be taken into account when studying entrepreneurship.

These four dimensions - the individual, the process, the organization and the environment - correspond to Gartner's (1985) framework for studying entrepreneurship.

However, the three variables chosen - the individual, the process and the organization - cover a large part of the issues in social entrepreneurship. The third section of this chapter classifies the American and European scholarship in social entrepreneurship according to these geographical and thematic criteria.

\section{ANALYSIS OF THE LITERATURE}

For the purpose of our literature review, we have examined the publications of each geographical school regarding the different thematic criteria. As we have seen, some scholars have followed an indicative approach and focused on the motivations of the founder of the social initiative. Let us first examine the importance attached to the personality and role of the social entrepreneur by the different approaches.

\subsection{The Individual: The Social Entrepreneur}

The social entrepreneur is more or less central to the different schools of thought. The social entrepreneur can be defined as a person whose main objective is not to make profit but to create social value for which he/she will adopt an entrepreneurial behaviour.

The Social Innovation School clearly distinguishes itself from the two others by the importance attached to the individual in its conception of social entrepreneurship. According to this approach, the concept of social entrepreneurship refers to the qualities of innovation (Austin et al., 2006; Mair and Martí, 2004) and creativity of the social entrepreneur in her or his pursuit of opportunities (Weerawardena and Sullivan Mort, 2006; Roberts and Woods, 2005). The main definitions of the social entrepreneur according to this school of thought are compiled in Appendix B. There seems to be an agreement among the Social Innovation School's scholars on several features of the social entrepreneur. ${ }^{7}$ According to this school, social entrepreneurs:

- Adopt a visionary and innovative approach (Roberts and Woods, 2005; Skoll, cited in Dearlove, 2004; Sullivan Mort et al., 2003; De 
1982) found that the environinto account when studying

the process, the organization tner's (1985) framework for

ndividual, the process and the es in social entrepreneurship. the American and European ing to these geographical and

\section{URE}

: have examined the publicahe different thematic criteria. $\mathrm{d}$ an indicative approach and of the social initiative. Let us 2 personality and role of the ies.

al to the different schools of ned as a person whose main social value for which he/she

inguishes itself from the two dividual in its conception of proach, the concept of social rovation (Austin et al., 2006; social entrepreneur in her or a and Sullivan Mort, 2006; itions of the social entreprere compiled in Appendix B. Social Innovation School's epreneur. ${ }^{7}$ According to this

coach (Roberts and Woods, dllivan Mort et al., 2003; De
Leeuw, 1999; Catford, 1998; Dees, 1998a; Drayton in Bornstein, 1998; Schuyler, 1998; Schwab Foundation, 1998). According to the Schumpeterian narrative of entrepreneurship, social entrepreneurs are essentially 'social innovators' (Nicholls and Cho, 2008).

- Are characterized by a strong ethical fibre (Catford, 1998; Drayton in Bornstein, 1998).

- Show a particular ability to detect opportunities (Sullivan Mort et al., 2003; Thompson et al., 2000; Catford, 1998; Dees, 1998a).

- Play a key role as 'Society's change agents' (Chell, 2007; Sharir and Lerner, 2006; Skoll in Dearlove, 2004; Thompson et al., 2000; Dees, 1998a; Schuyler, 1998). The Schumpeterian definition of the entrepreneur definitely is at the basis of this school's conception since social entrepreneurs can be considered as individuals who reform or revolutionize traditional production schemes of social value creation in moving resources towards places which offer superior return for society (Dees and Battle Anderson, 2006).

- Without being limited by resources currently at hand; otherwise, they gather them and use these to 'make a difference' (Peredo and McLean, 2006; Sharir and Lerner, 2006; Thompson et al., 2000; Dees, 1998a; Schuyler, 1998).

To sum up, according to this view, the social entrepreneur is a visionary individual who is able to identify and exploit opportunities; to leverage the resources necessary to the achievement of his/her social mission and to find innovative solutions to social problems of his/her community that are not adequately met by the local system.

However, the centrality of the individual figure in the Social Innovation School does not mean that other approaches of social entrepreneurship. do not pay any attention at all to the social entrepreneur although for the Social Enterprise School and the EMES Network, social entrepreneurship is a more collective action. For the former, the initiative must come from a non-profit organization or from the state. Here, the social entrepreneur plays a secondary role as the one who organizes and manages socialpurpose activities. Nicholls (2008: preface, p. xiii) very recently wrote that the focus on 'hero entrepreneurs' is 'effectively the tip of a socially entrepreneurial iceberg [. . .] most social entrepreneurship is in reality the product of groups, networks, and formal and informal organizations'.

The EMES approach does not exclude the possibility for some leader or charismatic entrepreneur to play a key role in the enterprise, but generally these persons are supported by a group whose members are responsible for the public benefit mission of the social enterprise (Defourny and Nyssens, 2006). But in the European perspective in general, social entrepreneurship 
is more a collective action, "where the social entrepreneur is embedded in a network of support/advice that helps this new way of entrepreneurship succeed' (Hulgard and Spear, 2006: 88-9). Spear (2006) argues that individualistic entrepreneurship in worker cooperatives is rather the exception than the rule. For the EMES Network, the social enterprise is an initiative that comes from a group of citizens - what Hulgard (2008) calls the 'active citizenship' - self-help dynamics, public-associative partnerships, and so on (Defourny, 2004). Moreover, research about community entrepreneurship (Johannisson and Nilsson, 1989; Stöhr, 1990) attests to the collective aspect usually ascribed to entrepreneurship in Europe.

Being of first or second importance depending on the school of thought, the social entrepreneur seems to bear several features. Nevertheless, one could ask whether these features are specific to social entrepreneurs. What defines an element is a set of peculiar characteristics that enable it to be distinguished from other elements, be they commercial entrepreneurship or other non-entrepreneurial social activities. Therefore, a comparative approach is essential in the process of defining a field and its core concepts.

Despite all these attempts to define social entrepreneurs, it seems that they share many characteristics with 'commercial' entrepreneurs: they have the same focus on vision and opportunity and the same ability to convince and empower others to help them turn their ideas into reality (Catford, 1998). We agree with Dees (1998a) according to whom social entrepreneurs would be a 'sub-species' of the entrepreneurs' family. However, although there is a lot of overlap between social entrepreneurs and their commercial counterparts - particularly leadership, vision, drive and opportunism - the main difference is that 'social entrepreneurs usually have a vision of something that they would like to solve in the social sector or a socio-moral motivation in their entrepreneurial focus and ambition' (Nicholls, 2008: 20). On the other hand, business entrepreneurs look at a problem from a purely economic point of view (Dearlove, 2004) whereas social entrepreneurs' acts will always be linked to an objective of social value creation (Sharir and Lerner, 2006; Sullivan Mort et al., 2003; Dees, 1998a; Schwab Foundation, 1998). It is possible to compare the two types of entrepreneurs according to several variables. Thalhuber (1998) suggests using four criteria to distinguish between social and commercial entrepreneurs. The former draw their strengths from collective wisdom and experience rather than from personal competences and knowledge; they focus on long-term capacity rather than short-term financial gains; their ideas are limited by their mission; they see profit as a means in people's service that has to be reinvested in future profit rather than an end to be distributed to shareholders. Finally, Brouard (2006) adds that social entrepreneurs risk the organization's their freedom limit

As in the entrepr social entrepreneu The next section in

\subsection{The Process:}

First, the mission expressed in terms formation' (Rober al., 2006; Weeraw social mission is a presents numerous American literatur the organizational

For Dees (1998 social mission with the characteristic and Sullivan Mort School, social valı on profit and weal pursuit of social ge - along with the pr is guaranteed by $t$ ily structured as a to the fulfilment all the social acti rather stress the $\mathrm{f}$ within the Thirds EMES Network, objective of servic questions. In the 1 be driven by their of thought clearly of social entreprer

Second, some intense link betwe approaches requir Innovation Scho 'the nature of the (Defourny and $\mathrm{N}$ 
ne social entrepreneur is embedded in lps this new way of entrepreneurship $88-9)$. Spear (2006) argues that indier cooperatives is rather the exception $\mathrm{rk}$, the social enterprise is an initiative - what Hulgard (2008) calls the 'active iblic -associative partnerships, and so arch about community entrepreneur; Stöhr, 1990) attests to the collective urship in Europe.

2 depending on the school of thought, ir several features. Nevertheless, one specific to social entrepreneurs. What ar characteristics that enable it to be e they commercial entrepreneurship 1 activities. Therefore, a comparacess of defining a field and its core

Ie social entrepreneurs, it seems that ih 'commercial' entrepreneurs: they opportunity and the same ability to lp them turn their ideas into reality s (1998a) according to whom social cies' of the entrepreneurs' family. verlap between social entrepreneurs particularly leadership, vision, drive $e$ is that 'social entrepreneurs usually vould like to solve in the social sector entrepreneurial focus and ambition' nd, business entrepreneurs look at a nt of view (Dearlove, 2004) whereas be linked to an objective of social 06; Sullivan Mort et al., 2003; Dees, is possible to compare the two types variables. Thalhuber (1998) suggests een social and commercial entrepres from collective wisdom and experitences and knowledge; they focus on term financial gains; their ideas are it as a means in people's service that ther than an end to be distributed to adds that social entrepreneurs risk the organization's assets rather than personal and investors' funds, and see their freedom limited by donors rather than employers.

As in the entrepreneurship field of research, some scholars tried to define social entrepreneurship without referring to the person but to the process. The next section investigates the process of social entrepreneurship.

\subsection{The Process: Social Entrepreneurship}

First, the mission is at the heart of the venture creation process. Be it expressed in terms of 'social change' (Mair and Martí, 2004), 'social transformation' (Roberts and Woods, 2005), 'social value creation' (Austin et al., 2006; Weerawardena and Sullivan Mort, 2006) or 'social impact', the social mission is a central element for each of the perspectives. Appendix C presents numerous definitions of social entrepreneurship we can find in the American literature. Indeed, the European literature has focused more on the organizational aspect of social entrepreneurship than on the process.

For Dees (1998a), social entrepreneurship combines the passion of a social mission with an image of business-like discipline. Some authors add the characteristic of sustainability to the social initiative (Weerawardena and Sullivan Mort, 2006; Mair and Martí, 2004). For the Social Innovation School, social value creation and sustainable social improvements prevail on profit and wealth generation. For the Social Enterprise School also, the pursuit of social goals must be the first objective of social entrepreneurship -along with the pursuit of profit motives. The social nature of the initiative is guaranteed by the fact that, according to this approach, it is necessarily structured as a non-profit organization. Hence, any profit is allocated to the fulfilment of a social mission. Here, the social mission embraces all the social activities which non-profits can be involved in. Europeans rather stress the fact that social entrepreneurship most often takes place within the Third Sector (Defourny and Nyssens, 2008). According to the EMES Network, social entrepreneurship initiatives must have an explicit objective of service to community that embraces social and environmental questions. In the European legislations in general, social enterprises must be driven by their social goals. Despite some differences, the three schools of thought clearly agree on the fact that the social mission is at the heart of social entrepreneurship.

Second, some researchers investigated whether there has to be an intense link between the social mission and the productive activities. Two approaches require a direct link between the means and the end: the Social Innovation School and the EMES Network. According to the latter, 'the nature of the economic activity must be linked to the social mission' (Defourny and Nyssens, 2006: 12). In Europe in general, the productive 
activity must usually be related to the mission. In contrast, the Social Enterprise School, as well as the British tradition, do not require the link between the organization's social end and its activities to be direct. For the partisans of this school of thought, social entrepreneurship consists in the implementation, by non-profit organizations, of commercial dynamics developed in order to finance their social activities. According to Nicholls (2008: 11), 'social entrepreneurs subsidize their social activities either through exploiting profitable opportunities in the core activities of their not-for-profit venture or via for-profit subsidiary ventures and cross-sector partnerships with commercial corporations'. In other words, according to this approach, profit-generating activities must not necessarily be linked with the social mission of the non-profit organization. For the two other schools, a link between the activity and the mission is a central differentiating element.

Finally, what makes social entrepreneurship different from its commercial form? Whereas some researchers (Mair and Martí, 2004; Dees, 1998a) rather looked at the common points, others compared social entrepreneurship and commercial entrepreneurship. Some of them (Roberts and Woods, 2005; Marc, 1988) stressed its innovating side in terms of collection, use and combination of resources in building, evaluating and pursuing opportunities in a perspective of social transformation. For Austin et al. (2006), the distinction between social and commercial entrepreneurship should not be dichotomous but rather continuous. Therefore, they proposed a systematic approach to compare social and commercial entrepreneurship, based on four differentiating variables: market failure, mission, resource mobilization and performance measurement. Their proposition was four-fold. First, 'market failure will create differing entrepreneurial opportunities for social and commercial entrepreneurship' (Austin et al., 2006: 3). Second, the mission will be a fundamental criterion to distinguish between social and commercial entrepreneurship. Third, there will be prevailing differences between both approaches in the way human and financial resources are mobilized and managed. Fourth, measuring social performance will be a fundamental differentiator since it will make accountability and relations with stakeholders more complex. Brouard (2006) based his comparison on the social and commercial roles of the entrepreneurial initiatives. For him, the commercial role is represented by two dimensions, namely the presence of commercial exchanges and the repartition of commercial profit. He believes that social entrepreneurship must pay exclusive, or at least majority, attention to the social role, commercial role being accessory. Moreover, he suggests that there can be commercial exchanges but that the entirety or the majority of the commercial profit has to be reinvested in the social mission rather than distributed to shareholders. The corporate social $\mathrm{r}$ primacy to the so importance of thi as we will see in $t$

\subsection{The Organiz}

American and Ex different. Append from the different differ in the way form and profit d

We define this nomic risk. In $\mathrm{E}$ common definitic national realities. the one hand, fou sions of the socia and/or services $p$ a significant leve work. On the oth of the initiatives: tiative launched on capital owner stakeholders; an normative but ra

In the United quite vague con activities serving Enterprise Schoc focuses on the preneurship org between moral articulate a con model and comn as being non-pro order to survive and subsidies th social enterprise fact that it com entrepreneurial 
mission. In contrast, the Social tradition, do not require the link and its activities to be direct. For social entrepreneurship consists in inizations, of commercial dynamir social activities. According to Irs subsidize their social activities pportunities in the core activities or-profit subsidiary ventures and ial corporations'. In other words, ating activities must not necessare non-profit organization. For the stivity and the mission is a central

urship different from its commer(air and Martí, 2004; Dees, 1998a) others compared social entrepreship. Some of them (Roberts and nnovating side in terms of collec$n$ building, evaluating and pursuial transformation. For Austin et and commercial entrepreneurship continuous. Therefore, they proe social and commercial entrepreariables: market failure, mission, measurement. Their proposition 11 create differing entrepreneurial ial entrepreneurship' (Austin et e a fundamental criterion to disil entrepreneurship. Third, there th approaches in the way human nd managed. Fourth, measuring 1 differentiator since it will make holders more complex. Brouard cial and commercial roles of the commercial role is represented by f commercial exchanges and the eves that social entrepreneurship attention to the social role, com1e suggests that there can be comir the majority of the commercial aission rather than distributed to shareholders. The main difference between social entrepreneurship and corporate social responsibility lies in the fact that the latter does not give primacy to the social role although it is aware of it. Let us stress that the importance of this difference may vary between the different approaches, as we will see in the next section devoted to the social venture.

\subsection{The Organization: The Social Enterprise}

American and European conceptions of the social enterprise are slightly different. Appendix D presents the main definitions of the social enterprise from the different geographical perspectives. The different schools mainly differ in the way they approach the enterprise concept, the organizational form and profit distribution.

We define this concept of 'enterprise' as an activity marked by an economic risk. In Europe, researchers of the EMES Network elaborated a common definition of the social enterprise in order to analyse the various national realities. Their definition is based on two series of indicators. On the one hand, four criteria reflect the economic and entrepreneurial dimensions of the social initiatives considered: (1) a continuous activity of goods and/or services production and sale; (2) a high degree of autonomy; (3) a significant level of economic risk; 8 and (4) a minimum amount of paid work. On the other hand, five indicators encapsulate the social dimensions of the initiatives: (1) an explicit aim to benefit the community; (2) an initiative launched by a group of citizens; (3) a decisional power not based on capital ownership; (4) a participatory nature including all the activity's stakeholders; and (5) limited profit distribution. This definition is not normative but rather an ideal-type.

In the United States, the social enterprise remains a broad and often quite vague concept referring primarily to market-oriented economic activities serving a social goal (Defourny and Nyssens, 2006). The Social Enterprise School also considers the 'enterprise' as central. This approach focuses on the double (sometimes triple) bottom line of social entrepreneurship organizations. Social entrepreneurs are those who balance between moral imperatives and the profit motives (Boschee, 1995) or articulate a compelling social impact theory with a plausible business model and commercial objectives. This approach defines social enterprises as being non-profit organizations that set up profit-generating activities in order to survive financially and become more independent of donations and subsidies they receive. The two main elements that characterize a social enterprise for the partisans of the Social Enterprise School are the fact that it combines a social objective - creating social value - with an entrepreneurial strategy - applying business expertise and market-based 
skills to non-profit organizations. This school of thought aims at the sustainability of social enterprises and promotes complete self-sufficiency of non-profits, which can be reached only through income generation and not through dependency on public and private sectors (Boschee and McClurg, 2003). Indeed, according to Boschee (2001), the 'ideal' way to tackle a social need is to answer it autonomously without being accountable to stakeholders. In contrast to the European perspective, ${ }^{9}$ the Social Enterprise School only stresses the risks associated with market income.

Finally, as mentioned above, the American Social Innovation School focuses on the social entrepreneur and his/her qualities, rather than on the organization and its specificities. According to this approach, the social enterprise is an activity set up by a social entrepreneur and there is no mention of any criterion of economic risk.

Therefore, we conclude that the concept of 'enterprise' is central for the EMES network as well as for the Social Enterprise School.

Another important issue that arose from our literature review is the question of the legal organizational form of the social enterprise. Does the social mission of the social enterprise imply that it cannot exist under any other legal organizational form than the non-profit form?

According to the Social Innovation School, the social enterprise can adopt either a non-profit or a for-profit organizational form. For Austin et al. (2006), as well as Mair and Martí (2004), social enterprises should not be limited to any specific legal form. According to these authors, the choice should rather be dictated by the nature of the social needs addressed and the amount of resources needed. To Mair and Martí (2004), the important element is the entrepreneurial spirit that gives the initiatives their social entrepreneurial nature. This perspective has resulted in the emergence of various hybrid organizational forms: independent, they can generate profit, employ people and hire volunteers, as well as adopt innovative strategies in their pursuit of social change. The advantages of these hybrid organizations include, among others, a higher market response rate, higher efficiency and innovation rates, as well as a larger capacity to mobilize resources (Dees and Battle Anderson, 2006; Haugh, 2005).

On the other hand, for the Social Enterprise School, at least at its beginning, social enterprises had to be non-profits that used an earned income strategy in order to generate revenue in support of their charitable mission. Earned income can be defined as 'income derived from selling products or services' (Battle Anderson and Dees, 2008: 145) to contrast with the idea of philanthropic donations or government subsidies. However, since the mid-1990s the Social Enterprise School has considered a social enterprise as any business that trades for a social purpose (Austin et al., 2006).

Finally, in some European countries, a specific legal form has been created in order to e case has demonstrat growth thanks to the 2001). Indeed, by leg saw their number in other European cou entrepreneurial appr In 1995, Belgium in Portugal (1997), we (2002) of "cooperativ of "work insertion sc than ten years after British Blair gover as an independent which aims at playi bility through busi hybrid organization company. Despite a prises across Europ time, namely associ (Defourny and Nys

Directly linked to issue for social ente

The Social Innov profit distribution. neur's activity gene social object, but th the social added val

In contrast, the distribution as, acc social enterprises $c$ Profit was therefor version, the Social business, which, c owners or workers sented the different characterized by th value. These strate tive, the scope of $i$ which profit is dec traditional for-pro organizations. On 
This school of thought aims at the id promotes complete self-sufficiency ed only through income generation lic and private sectors (Boschee and to Boschee (2001), the 'ideal' way to itonomously without being accounthe European perspective, ${ }^{9}$ the Social sks associated with market income.

American Social Innovation School $\mathrm{d}$ his/her qualities, rather than on the cording to this approach, the social social entrepreneur and there is no risk.

ncept of 'enterprise' is central for the ial Enterprise School.

se from our literature review is the rm of the social enterprise. Does the imply that it cannot exist under any the non-profit form?

on School, the social enterprise can fit organizational form. For Austin artí (2004), social enterprises should form. According to these authors, 1 by the nature of the social needs s needed. To Mair and Martí (2004), heurial spirit that gives the initiatives This perspective has resulted in the itional forms: independent, they can re volunteers, as well as adopt innocial change. The advantages of these $g$ others, a higher market response rates, as well as a larger capacity to inderson, 2006; Haugh, 2005).

aterprise School, at least at its beginl-profits that used an earned income a support of their charitable mission. me derived from selling products or 2008: 145) to contrast with the idea Iment subsidies. However, since the ol has considered a social enterprise 1 purpose (Austin et al., 2006). ies, a specific legal form has been created in order to encourage and support social enterprises. The Italian case has demonstrated how the state may encourage social enterprises' growth thanks to the introduction of specific laws (Borzaga and Santuari, 2001). Indeed, by legally recognizing the 'social cooperatives' in 1991, Italy saw their number increase significantly. Following the Italian example, other European countries have introduced new legal forms that reflect the entrepreneurial approach adopted by an increasing number of non-profits. In 1995, Belgium introduced the status of 'social purpose company'. In Portugal (1997), we talk of 'social solidarity cooperatives', in France (2002) of 'cooperative societies of collective interest' and in Finland (2003) of 'work insertion social enterprises' (Defourny and Nyssens, 2006). More than ten years after the impulse given by Italy to social enterprises, the British Blair government defined the 'Community Interest Company' as an independent organization having social and economic objectives, which aims at playing a social role as much as reaching financial durability through business (DTI, 2001). This new legal form represents a hybrid organizational type, part not-for-profit, part equity offering limited company. Despite all these newly created legal forms, most social enterprises across Europe still adopt legal forms that have existed for a long time, namely associations or cooperatives - or traditional business forms (Defourny and Nyssens, 2008).

Directly linked to the legal form, profit distribution is also an important issue for social enterprises.

The Social Innovation School does not impose any constraint regarding profit distribution. According to this movement, if the social entrepreneur's activity generates benefits, these will preferably be reinvested in the social object, but this is not a strict obligation. Only the final increase of the social added value is important.

In contrast, the American Social Enterprise School forbids any profit distribution as, according to the definition of non-profit organizations, social enterprises cannot distribute profit to their directors or members. Profit was therefore entirely dedicated to the social objective. In its later version, the Social Enterprise School considers social enterprises as any business, which, consequently, authorizes some profit distribution to owners or workers. Alter (2004), in her 'Hybrid Spectrum Model', presented the different options of social strategies for hybrid organizations, characterized by the fact that they generate social as much as economic value. These strategies depend on three criteria: the enterprise's objective, the scope of its responsibility towards shareholders and the ends to which profit is dedicated. Between these two extremes (non-profits and traditional for-profits), Alter (2004) distinguished four types of hybrid organizations. On the one hand, social enterprises and non-profits having 
income generating activities ${ }^{10}$ try to have a social impact on society. On the other hand, socially responsible organizations' and practising social responsibility organizations' primary objective is the search for profit. Therefore, in this model, social enterprises are characterized by a social mission, a high responsibility towards stakeholders and the reinvestment or their income in social programmes or operational costs, in contrast with profit distribution to shareholders, totally prohibited by this school.

Finally, the European approach advocates a limit to profit distribution. According to the EMES Network, the social enterprise, in its choice of the way it will distribute benefits, must avoid a behaviour that would lead to profit maximization. Hence, the social enterprise can distribute profit, but in a limited manner.

The next section concludes whether, according to our analysis of the literature, there is a transatlantic divide in the way of approaching social entrepreneurship.

\section{CONCLUSION: A TRANSATLANTIC DIVIDE OR A MORE COMPLEX PICTURE?}

Social entrepreneurship can be seen as a source of solutions to certain illnesses of our modern societies. The utility of social enterprises as an instrument for governments has been recognized, for example, in the UK where a lending agency for social enterprises has been set up. Be they as a way to subcontract public services or as a means to improve these services without increasing the state's domain (Cornelius et al., 2007), social entrepreneurship initiatives are growing in number and importance. Unfortunately, from an academic point of view, research in the field of social entrepreneurship has long remained descriptive and, sometimes, partisan.

From our in-depth literature review on social entrepreneurship, we have identified three main schools of thought. Two schools studying the phenomenon of social entrepreneurship from different perspectives have emerged in the United States. The Social Innovation School stresses the importance of the social entrepreneur as an individual and focuses on his/ her features. The Social Enterprise School claims that this kind of organization will survive by conducting profit-generating activities in order to finance social value creation. The European tradition approaches social entrepreneurship by creating specific legal forms for social enterprises. On the other hand, three major themes have also emerged from the classical literature in entrepreneurship: the individual, the process and the organization. The review of the definitions of the main concepts of the field 
e a social impact on society. On the zations' and practising social respon$e$ is the search for profit. Therefore, haracterized by a social mission, a lers and the reinvestment or their tional costs, in contrast with profit ohibited by this school.

ocates a limit to profit distribution. social enterprise, in its choice of the oid a behaviour that would lead to enterprise can distribute profit, but

$\therefore$ according to our analysis of the $e$ in the way of approaching social

\section{LANTIC DIVIDE OR A}

is a source of solutions to certain utility of social enterprises as an ecognized, for example, in the UK erprises has been set up. Be they is or as a means to improve these domain (Cornelius et al., 2007), rowing in number and importance. it of view, research in the field of ained descriptive and, sometimes,

$N$ on social entrepreneurship, we hought. Two schools studying the $p$ from different perspectives have ial Innovation School stresses the $\mathrm{s}$ an individual and focuses on his/ ool claims that this kind of organiit-generating activities in order to spean tradition approaches social yal forms for social enterprises. On ve also emerged from the classical idual, the process and the organiof the main concepts of the field enabled us to identify six criteria that we used in order to analyse common points and differences between the different approaches: the entrepreneur; the intensity of the social mission; the intensity of the link between the organization's activities and its first goal; the importance of the enterprise as an organizational structure; its legal form; and the limitation of profit distribution. Crossing the three schools of social entrepreneurship with the six above-mentioned criteria, we obtain a $6 \times 3$ matrix. Table 7.1 summarizes the results of our literature review in terms of the position of each school of thought of social entrepreneurship regarding each thematic criterion.

To sum up, we observed that the figure of the entrepreneur is central only to the Social Innovation School of thought that highlights individual profiles, whereas, in Europe, the focus is rather on collective modes of organization and less on individuals. The social mission is clearly acknowledged as the primary objective of social entrepreneurship, even if it has been expressed in different ways by all the three approaches. Although the Social Innovation School and the EMES Network require a direct link between the enterprise's social mission and its productive activities, the Social Enterprise School advocates that the link between social mission and income-generating activities can be more or less strong. The flag of 'social enterprise' is probably the most controversial (Defourny and Nyssens, 2008). Indeed, the social enterprise is a key element in the European tradition as well as for the Social Enterprise School according to which social enterprises are self-financed undertakings with a social aim. The latter considers non-profit social enterprises whereas the European tradition imposes some constraints regarding the legal form. Therefore, linked to the legal framework, profit distribution is almost totally prohibited by the Social Enterprise School and partially limited in the EMES approach in order to protect the primacy of the social mission. The Social Innovation School does not impose any constraint: the choice regarding the legal form and profit distribution should rather be dictated by the nature of the social needs addressed and the amount of resources needed.

Before starting this work, one could have thought that there would have been a clear-cut transatlantic divide in the way of approaching and defining social entrepreneurship. This assumption could be based on the way Europe and the United States consider the government's role and, consequently, social entrepreneurship's role. Indeed, if the American and European literatures agree on the fact that the first goal of social entrepreneurship must be the creation of social value, one can clearly distinguish them on basis of the central role played by public policies in Europe compared to the government-detached American approach. However, there is no such divide. Even within the United States, there are different 
Table 7.1 Classification of geographical schools of thought of social entrepreneurship by thematic criteria

\begin{tabular}{|c|c|c|c|c|c|}
\hline \multirow[t]{2}{*}{ Themes } & & \multirow[t]{2}{*}{ Criteria } & \multicolumn{2}{|c|}{$\begin{array}{l}\text { AMERICAN } \\
\text { TRADITION }\end{array}$} & \multirow{2}{*}{$\begin{array}{l}\text { EUROPEAN } \\
\text { TRADITION } \\
\text { The EMES } \\
\text { Network }\end{array}$} \\
\hline & & & $\begin{array}{l}\text { The Social } \\
\text { Innovation } \\
\text { School }\end{array}$ & $\begin{array}{l}\text { The Social } \\
\text { Enterprise } \\
\text { School }\end{array}$ & \\
\hline INDIVIDUAL & 1. & $\begin{array}{l}\text { The entre- } \\
\text { preneur }\end{array}$ & $\begin{array}{l}\text { Central } \\
\text { figure }\end{array}$ & $\begin{array}{l}\text { Secondary } \\
\text { importance }\end{array}$ & $\begin{array}{l}\text { Collective } \\
\text { dynamics: } \\
\text { initiative } \\
\text { launched by a } \\
\text { group of citizens }\end{array}$ \\
\hline \multirow[t]{2}{*}{ PROCESS } & 2. & The mission & $\begin{array}{l}\text { The innovation } \\
\text { process is } \\
\text { primarily } \\
\text { oriented to } \\
\text { a soci(et)al } \\
\text { change }\end{array}$ & $\begin{array}{l}\text { These } \\
\text { organizations } \\
\text { allocate } \\
\text { market } \\
\text { resources to } \\
\text { the fulfilment } \\
\text { of a social } \\
\text { mission }\end{array}$ & $\begin{array}{l}\text { Explicit aim } \\
\text { to benefit the } \\
\text { community }\end{array}$ \\
\hline & 3. & $\begin{array}{l}\text { Link social } \\
\text { mission- } \\
\text { productive } \\
\text { activities }\end{array}$ & $\begin{array}{l}\text { Direct: } \\
\text { innovative } \\
\text { strategies to } \\
\text { tackle social } \\
\text { needs are } \\
\text { implemented } \\
\text { through the } \\
\text { provision of } \\
\text { goods and } \\
\text { services }\end{array}$ & $\begin{array}{l}\text { No constraint: } \\
\text { the trading } \\
\text { activity } \\
\text { is simply } \\
\text { considered as } \\
\text { a source of } \\
\text { income, so SE } \\
\text { can develop } \\
\text { business } \\
\text { activities } \\
\text { unrelated } \\
\text { to the social } \\
\text { mission to } \\
\text { provide } \\
\text { financial } \\
\text { resources }\end{array}$ & $\begin{array}{l}\text { Direct: the } \\
\text { productive } \\
\text { activity is related } \\
\text { to the social } \\
\text { mission of the SE }\end{array}$ \\
\hline \multirow[t]{2}{*}{ ORGANIZATION } & 4. & $\begin{array}{l}\text { The } \\
\text { enterprise }\end{array}$ & $\begin{array}{l}\text { Secondary } \\
\text { importance: } \\
\text { activity set } \\
\text { up by a social } \\
\text { entrepreneur }\end{array}$ & $\begin{array}{l}\text { Central: stress } \\
\text { on the risks } \\
\text { associated } \\
\text { with market } \\
\text { income }\end{array}$ & $\begin{array}{l}\text { Central: } \\
\text { significant level } \\
\text { of economic risk }\end{array}$ \\
\hline & 5. & $\begin{array}{l}\text { The legal } \\
\text { form }\end{array}$ & $\begin{array}{l}\text { No clear } \\
\text { constraint: } \\
\text { the choice } \\
\text { regarding the } \\
\text { legal form } \\
\text { should be }\end{array}$ & $\begin{array}{l}\text { 1st Early } \\
\text { version: focus } \\
\text { on non-profits } \\
\text { 2nd Later } \\
\text { version: stress } \\
\text { on any }\end{array}$ & $\begin{array}{l}\text { Some } \\
\text { constraints: } \\
\text { new legal forms } \\
\text { and specific } \\
\text { frameworks have } \\
\text { been created to }\end{array}$ \\
\hline
\end{tabular}

Table 7.1 (continued)

Themes

Source: Partially adapted $\mathrm{f}$

conceptions. These con have resulted in vario concept of social entre

In terms of direction neurship, this implies object are not differen social entrepreneurshi also observed differenc as long as definitions clearly announce the $\mathrm{p}$

This work was a fir: broad field of research comparative analysis European publication However, several pers in the fact that Nort approaches to entrep analysis of the differer would be of prime inte could result in differer 
or regional areas. Finally, tensions between the social mission and market requirements have been recognized by numerous authors as the central definitional element of social entrepreneurship. However, little research has been conducted so far on the way this can be managed. Therefore, the role of management practices in solving these tensions should be examined more deeply.

\section{NOTES}

1. Some parts of this chapter constitute an early version of a manuscript that has been accepted for publication in Entrepreneurship and Regional Development, special issue on Community-based, Social \& Societal Entrepreneurship.

2. Florence Nightingale, a British pioneer, fought to improve the hospital conditions during the Crimean War in the nineteenth century, making the mortality rate drop from 40 per cent to 2 per cent. Roshaneh Zafar, founder of the Kashf Foundation, has fought for the economic condition of women in Pakistan by opening thousands of microcredit institutions (Dearlove, 2004). Fundación Social in Colombia was established in 1911 with the aim of generating and devoting revenues to the creation of social value (Fowler, 2000).

3. In 1996, university research centres and researchers from the fifteen member states of the European Union set up a scientific network whose name, 'EMES', refers to the title of its first research programme on the 'Emergence of social enterprises in Europe'.

4. A 'not-for-profit' means any venture whose very first aim is a social purpose rather than profit making. Hence, a not-for-profit can be profitable and distribute profit in a limited way in agreement with its social mission, in contrast with purely 'non-profit' enterprises.

5. The reader will find a classification of the main authors of each of these two approaches in Appendix A.

6. Among the most important ones, let us cite Echoing Green (1987), The Schwab Foundation for Social Entrepreneurs (1998), The Skoll Foundation (1999) and The Manhattan Institute's Social Entrepreneurship Initiative (2001).

7. The words in boldface in Appendix B represent these features.

8. According to EMES, social enterprises must bear a significant level of economic risk, which means that "the financial viability of the social enterprise depends on the efforts of its members to secure adequate resources to support the enterprisess social mission' and that 'these resources can have a hybrid character and come from trading activities, from public subsidies and from voluntary resources obtained thanks to the mobilization of social capital' (Defourny and Nyssens, 2008, 2006).

9. With the exception of the United Kingdom where, according to the CIC legislation, it is commonly admitted that 50 per cent of the total income of a social enterprise must be market-based.

10. This kind of hybrid organization is very close to Fowler's (2000) idea of 'complementary social entrepreneurship'.

\section{REFERENCES}

Acs, Z.J. and D.B. Audretsch (2003), 'Introduction to the Handbook of Entrepreneurship Research', in Z.J. Acs and D.B. Audretsch (eds), Handbook of Entre- preneurship Research: An Kluwer Academic Publis

Acs, Z.J. and K. Kallas (20 prises and entrepreneursl Entrepreneurship, growt Entrepreneurship, Growt Alter, K. (ed.) (2004), Socia Alvord, S.H., L.D. Brown social transformation: a Science, 40(3), 260-82.

Austin, J., H. Stevenson an preneurship: same, differ 31(1), 1-22.

Battle Anderson, B. and G. a solid foundation for th (ed.), Social Entreprene Oxford: Oxford Universi

Blackburn, R. and M. R limitations of entreprene Entrepreneurship and Reg

Bornstein, D. (1998), 'Chan 281(1), 34-9.

Borzaga, C. and A. Santua1 vative social enterprises', of Social Enterprise, Lon

Boschee, J. (1995), 'Social e about the unthinkable, th Conference Board Magaz

Boschee, J. (2001), 'Eight b World, 19(4), 15-18.

Boschee, J. and J. McClurg preneurship: some impo www.se-alliance.org/bett

Brazael, D.V. and T. I Entrepreneurship Theory

Brock, D.D. (ed.) (2006) S Kentucky: Entrepreneurs

Brouard, F. (2006), 'L'entr presented at the Annual and Entrepreneurship, T

Brouard, F. (2007), 'Réflex the Administrative Scien

Brush, C.G., T.S. Manolor language? Entrepreneur Theory and Practice, 32(

Bruyat, C. and P.-A. Julien ship', Journal of Business

Casson, M. (ed.) (1982), Th Robertson.

Catford, J. (1998), 'Social 
$n$ the social mission and market imerous authors as the central Irship. However, little research can be managed. Therefore, the ese tensions should be examined

version of a manuscript that has been t Regional Development, special issue on leurship.

ht to improve the hospital conditions ry, making the mortality rate drop from ler of the Kashf Foundation, has fought istan by opening thousands of microSocial in Colombia was established in revenues to the creation of social value

hers from the fifteen member states of whose name, 'EMES', refers to the title ice of social enterprises in Europe'.

ery first aim is a social purpose rather $n$ be profitable and distribute profit in on, in contrast with purely 'non-profit' uthors of each of these two approaches Echoing Green (1987), The Schwab The Skoll Foundation (1999) and The Initiative (2001).

these features.

bear a significant level of economic of the social enterprise depends on the urces to support the enterprise's social ybrid character and come from trading intary resources obtained thanks to the (yssens, 2008, 2006).

ere, according to the CIC legislation, it tal income of a social enterprise must be Fowler's (2000) idea of 'complementary

tion to the Handbook of Entrepreadretsch (eds), Handbook of Entre- preneurship Research: An Interdisciplinary Survey and Introduction, Dordrecht: Kluwer Academic Publishers, pp. 3-20.

Acs, Z.J. and K. Kallas (2007), 'State of literature on small to medium-size enterprises and entrepreneurship in low-income communities', Discussion Paper on Entrepreneurship, growth and public policy no. 0307, Jena, Germany: Group Entrepreneurship, Growth and Public Policy.

Alter, K. (ed.) (2004), Social Enterprise Typology, Virtue Ventures LLC.

Alvord, S.H., L.D. Brown and C.W. Letts (2004), 'Social entrepreneurship and social transformation; an exploratory study', Journal of Applied Behavioral Science, 40(3), 260-82.

Austin, J., H. Stevenson and J. Wei-Skillern (2006), 'Social and commercial entrepreneurship: same, different, or both?', Entrepreneurship Theory and Practice, 31(1), 1-22.

Battle Anderson, B. and G. Dees (2008), 'Rhetoric, reality, and research: building a solid foundation for the practice of social entrepreneurship', in A. Nicholls (ed.), Social Entrepreneurship: New Models of Sustainable Social Change, Oxford: Oxford University Press, pp, 144-80.

Blackburn, R. and M. Ram (2006), 'Fix or fixation? The contributions and limitations of entrepreneurship and small firms to combating social exclusion', Entrepreneurship and Regional Development, 18(1), 73-89.

Bornstein, D. (1998), 'Changing the world on a shoestring', The Atlantic Monthly, 281(1), 34-9.

Borzaga, C. and A. Santuari (2001), 'Italy: from traditional co-operatives to innovative social enterprises', in C. Borzaga and J. Defourny (eds), The Emergence of Social Enterprise, London: Routledge, pp. 166-81.

Boschee, J. (1995), 'Social entrepreneurship: some nonprofits are not only thinking about the unthinkable, they're doing it - running a profit', Across the Board, The Conference Board Magazine, 32(3), 20-25.

Boschee, J. (2001), 'Eight basic principles for nonprofit entrepreneurs', Nonprofit World, 19(4), 15-18.

Boschee, J. and J. McClurg (2003), 'Toward a better understanding of social entrepreneurship: some important directions', working paper, available at http:// www.se-alliance.org/better_understanding.pdf.

Brazael, D.V. and T. Herbert (1999), 'The genesis of entrepreneurship', Entrepreneurship Theory and Practice, 23(3), 29-45.

Brock, D.D. (ed.) (2006) Social Entrepreneurship Teaching Resources Handbook, Kentucky: Entrepreneurship for the Public Good, Berea College.

Brouard, F. (2006), 'L'entrepreneuriat social, mieux connaitre le concept', paper presented at the Annual Conference of the Canadian Council for Small Business and Entrepreneurship, Trois-Rivières.

Brouard, F. (2007), 'Réflexions sur l'Entrepreneuriat Social', paper presented at the Administrative Sciences Association of Canada, Ottawa.

Brush, C.G., T.S. Manolova and L.F. Edelman (2008), 'Separated by a common language? Entrepreneurship research across the Atlantic', Entrepreneurship Theory and Practice, 32(2), 249-66.

Bruyat, C. and P.-A. Julien (2001), 'Defining the field of research in entrepreneurship", Journal of Business Venturing, 16(2), 165-80.

Casson, M. (ed.) (1982), The Entrepreneur - An Economic Theory, Oxford: Martin Robertson.

Catford, J. (1998), 'Social entrepreneurs are vital for health promotion - but 

they need supportive environments too', Health Promotion International, 13(2),
95-7.

Chell, E. (2007), 'Social enterprise and entrepreneurship, towards a convergent theory of the entrepreneurial process', International Small Business Journal, 25(1), 5-26.

Christie, M.J. and B. Honig (2006), 'Social entrepreneurship: new research findings', Journal of World Business, 41(1), 1-5.

Cooney, K. (2006), 'The institutional and technical structuring of nonprofit ventures: case study of a US hybrid organization caught between two fields', Voluntas, 17(2), 143-61.

Cornelius, N., M. Todres, S. Janjuha-Jivraj, A. Woods and J. Wallace (2007), 'Corporate social responsibility and the social enterprise', Journal of Business Ethics, 76(1), 117-35.

Dart, R. (2004), 'The legitimacy of social enterprise', Nonprofit Management and Leadership, 14(4), 411-24.

Dearlove, D. (2004), 'Interview: Jeff Skoll', Business Strategy Review, 15(2), 51-3.

Dees, G. (1998a), "The meaning of "Social Entrepreneurship", Kauffman Foundation, pp. 1-5.

Dees, G. (1998b), 'Enterprising nonprofits', Harvard Business Review, 76(1), 54-6.

Dees, G. and B. Battle Anderson (2006), 'Framing a theory of social entrepreneurship: building on two schools of practice and thought', ARNOVA Occasional Paper Series - Research on Social Entrepreneurship: Understanding and Contributing to an Emerging Field, 1(3), 39-66.

Defourny, J. (2001), 'From Third Sector to social enterprise', in C. Borzaga and J. Defourny (eds), The Emergence of Social Enterprise, London/NY: Routledge, pp. 1-28.

Defourny, J. (2004), 'L'émergence du concept d'entreprise sociale', Reflets et Perspectives de la Vie Économique, 43(3), 9-23.

Defourny, J. and M. Nyssens (2006), 'Defining social enterprise', in M. Nyssens (ed.), Social Enterprises, At the Crossroads of Market, Public Policies and Civil Society, London: Routledge, pp. 3-26.

Defourny, J. and M. Nyssens (2008), 'Conceptions of social enterprise in Europe and the United States: convergences and divergences', paper presented at the EMES International Summer School, Corte, 3-7 July.

Degroote, N. (2008), 'L'enterprise sociale aux Etats-Unis et en Europe: analyse comparative de cinq approches', Master's Thesis, Thesis director: J. Defourney,

De Leeuw, E. (1999), 'Healthy cities: urban social entrepreneurship for health', Health Promotion. International, 14(3), 261-9.

Dorado, S. (2006), 'Social entrepreneurial ventures: different values so different process of creation, no?', Journal of Developmental Entrepreneurship, 11(4), 319-43.

Drayton, W. (2002), 'The citizen sector: becoming as entrepreneurial and competitive as business', California Management Review, 44(3), 120-32.

Drucker, P. (1985), Innovation and Entrepreneurship, New York: Harper and Row.

DTI (2001), 'Researching social enterprise', Final Report to the Small Business Service, available at http://www.dti.gsi.gov.uk/.

Emerson, Jed and Fay Twersky (1996), New Social Entrepreneurs: The Success, Challenge and Lessons of Non-profit Enterprise Creation, San Francisco: Roberts Foundation, Homeless Economic Development Fund. 
Health Promotion International, 13(2), atrepreneurship, towards a convergent International Small Business Journal,

al entrepreneurship: new research find-5 .

nd technical structuring of nonprofit ganization caught between two fields',

raj, A. Woods and J. Wallace (2007), social enterprise', Journal of Business

enterprise', Nonprofit Management and

Business Strategy Review, 15(2), 51-3. Social Entrepreneurship", Kauffman

its', Harvard Business Review, 76(1),

), 'Framing a theory of social entreof practice and thought', ARNOVA Social Entrepreneurship: Understanding (3), 39-66.

o social enterprise', in C. Borzaga and ial Enterprise, London/NY: Routledge,

ncept d'entreprise sociale', Reflets et , 9-23.

ining social enterprise', in M. Nyssens ids of Market, Public Policies and Civil

ceptions of social enterprise in Europe d divergences', paper presented at the orte, 3-7 July.

aux Etats-Unis et en Europe: analyse 's Thesis, Thesis director: J. Defourney. an social entrepreneurship for health', 51-9.

ventures: different values so different ovelopmental Entrepreneurship, 11(4),

coming as entrepreneurial and competiReview, 44(3), 120-32.

neurship, New York: Harper and Row. $\therefore$ Final Report to the Small Business ov.uk/.

Tew Social Entrepreneurs: The Success, rprise Creation, San Francisco: Roberts opment Fund.
European Commission (2003), The Social Situation in the European Union, Brussels: Commission of the European Union.

Filion, L.J. (1997), 'Le champ de l'entrepreneuriat: historique, evolution, tendances', Revue International P.M.E., 10(2), 129-72.

Fowler, A. (2000), "NGDOs as a moment in history: beyond aid to social entrepreneurship or civic innovation?', Third World Quarterly, 21(4), 637-54.

Gartner, W.B. (1985), 'A conceptual framework for describing the phenomenon of new venture creation', Academy of Management Review, 10(4), 696-706.

Gartner, W.B. (1988), "Who is an entrepreneur?" is the wrong question', American Journal of Small Business, 12(4), 11-32.

Guclu, A., G. Dees and B. Battle Anderson (2002), "The process of social entrepreneurship: creating opportunities worthy of serious pursuit', working paper, Center for the Advancement of Social Entrepreneurship (CASE).

Haugh, H. (2005), 'A research agenda for social entrepreneurship', Social Enterprise Journal, 1(1), 1-12.

Haugh, H. and P. Tracey (2004), "The role of social enterprise in regional development', paper presented to the Social Enterprise and Regional Development Conference, Cambridge-MIT Institute, University of Cambridge.

Hulgard, L. (2008), 'Discourses of social entrepreneurship in USA and Europe - variations of the same theme?', paper presented at the EMES International Summer School, Corte, 3-7 July,

Hulgard, L. and R. Spear (2006), 'Social entrepreneurship and the mobilization of social capital in European social enterprises', in M. Nyssens (ed.), Social Enterprises: At the Crossroads of Market, Public Policies and Civil Society, London/NY: Routledge, pp. 85-108.

Johannisson, B. and A. Nilsson (1989), 'Community entrepreneurship networking for regional development', Entrepreneurship and Regional Development, 1(1), 1-19.

Johnson, S. (2000), 'Literature review on social entrepreneurship', working paper, Canadian Centre for Social Entrepreneurship (CCSE): pp. 1-16, available at http://www.ccsecanada.org/.

Kerlin, J.A. (2006), 'Social enterprise in the United States and Europe: understanding and learning from the differences', Voluntas, 17(3), 246.

Kramer, M. (2005), 'Measuring innovation: evaluation in the field of social entrepreneurship', Skoll Foundation, Boston: Foundation Strategy Group.

Leadbeater, C. (ed.) (1997), The Rise of the Social Entrepreneur, London: Demos.

Light, P. (2005), 'Searching for social entrepreneurs: who they might be, where they might be found, what they do', paper presented at the Association for Research on Nonprofit and Voluntary Associations annual conference, 17-18 November.

Mair, J. and I. Martí (2004), 'Social entrepreneurship: what are we talking about? A framework for future research', working paper, IESE Business School, University of Navarra, pp. 1-14.

Mair, J. and I. Martí (2006), 'Social entrepreneurship research: a source of explanation, prediction and delight', Journal of World Business, 41(1), 36-44.

Mair, J. and E. Noboa (2006), 'Social entrepreneurship: how intentions to create a social venture are formed', in J. Mair, J.A. Robinson and K. Hockerts (eds), Social Entrepreneurship, Basingstoke, UK and New York: Palgrave Macmillan, pp. $121-35$. 
Marc, F. (1988), 'Nouvel entrepreneuriat et mission sociale de l'entreprise', paper presented at the International Conference, Montpellier.

McGrath, R.G. (2003), 'Connecting the study of entrepreneurship and theories of capitalist progress: an epilogue', in Z.J. Acs and D.B. Audretsch (eds), Handbook of Entrepreneurship Research, Boston/Dordrecht/London: Kluwer Academic Publishers, pp. 515-31.

Miller; D. and P.H. Friesen (1982), 'Innovation in conservative entrepreneurial fitms: two models of strategic momentum', Strategic Management Journal, 3, $1-25$.

Nicholls, A. (ed.) (2008), 'Social Entrepreneurship: New Models of Sustainable Social Change, Oxford: Oxford University Press (paperback edition).

Nicholls, A. and A.H. Cho (2008), 'Social entrepreneurship: the structuration of a field', in A. Nicholls (ed.), Social Entrepreneurship: New Models of Sustainable Social Change, Oxford: Oxford University Press (paperback edition), pp. 99-118.

Peredo, A.M. and M. McLean (2006), 'Social entrepreneurship: a critical review of the concept', Journal of World Business, 41(1), 56-65.

Roberts, D. and C. Woods (2005), 'Changing the world on a shoestring: the concept of social entrepreneurship', University of Auckland Business Review, Autumn, pp. 45-51.

Robinson, J. (2006), 'Navigating social and institutional barriers to markets: how social entrepreneurs identify and evaluate opportunities', in J. Mair, J. Robinson and K. Hockerts (eds), Social Entrepreneurship, Basingstoke, UK and New York: Palgrave Macmillan, pp. 95-120.

School for Social Entrepreneurs (SSE) (2002), available at http:/www.sse.org.uk/.

Schuyler, G. (1998), 'Social entrepreneurship: profit as means, not an end', Kauffman Center for Entrepreneurial Leadership Clearinghouse on Entrepreneurship Education Digest, 98(7), 1-3.

Schwab Foundation (1998), available at http://www.schwabfound.org/.

Shane, S. and S. Venkataraman (2000), "The promise of entrepreneurship as a field of research', Academy of Management Review, 25(1), 217-26.

Sharir, M. and M. Lerner (2006), 'Gauging the success of social ventures initiated by individual social entrepreneurs', Journal of World Business, 41(1), 6-20.

Smallbone, D., M. Evans, I. Ekanem and S. Butters (2001), 'Researching social enterprise', Centre for Enterprise and Economic Development Research, Middlesex University.

Spear, R. (2006), 'Social entrepreneurship: a different model?', International Journal of Social Economics, 33(5/6), 399-410.

Stöhr, W.B. (ed.) (1990), Global Challenge and Local Response: Initiatives for Economy Regeneration in Contemporary Europe, London/NY; The United Nations University - Mansell.

Stryjan, Y. (2006), 'The practice of social entrepreneurship: notes toward a resource-perspective', in C. Steyaert and D. Hjorth (eds), Entrepreneurship as Social Change: A Third Movements in Entrepreneurship Book, Cheltenham, UK and Northampton, MA, USA: Edward Elgar, pp. 35-55.

Sullivan Mort, G., J. Weerawardena and K. Carnegie (2003), 'Social entrepreneurship: towards conceptualization', International Journal of Nonprofit and Voluntary Sector Marketing, 8(1), 76-88.

Thalhuber, J. (1998), 'The definition of social entrepreneur', National Centre for Social Entrepreneurs, pp. 1-3. 
mission sociale de l'entreprise', paper e, Montpellier.

udy of entrepreneurship and theories Z.J. Acs and D.B. Audretsch (eds), l, Boston/Dordrecht/London: Kluwer

vation in conservative entrepreneurial m', Strategic Management Journal, 3,

'neurship: New Models of Sustainable y Press (paperback edition).

ntrepreneurship: the structuration of a "eneurship: New Models of Sustainable rsity Press (paperback edition), pp.

al entrepreneurship: a critical review of 11(1), 56-65.

iging the world on a shoestring: the iversity of Auckland Business Review,

nd institutional barriers to markets: valuate opportunities', in J, Mair, J. intrepreneurship, Basingstoke, UK and 120.

2), available at http://www.sse.org.uk/. ship: profit as means, not an end', ial Leadership Clearinghouse on $1-3$.

p://www.schwabfound.org/.

promise of entrepreneurship as a field view, 25(1), 217-26.

the success of social ventures initiated al of World Business, 41(1), 6-20.

ind S. Butters (2001), 'Researching nd Economic Development Research,

p: a different model?', International $-410$.

$e$ and Local Response: Initiatives for y Europe, London/NY: The United

al entrepreneurship: notes toward a D. Hjorth (eds), Entrepreneurship as trepreneurship Book, Cheltenham, UK lgar, pp. 35-55.

$\mathrm{K}$. Carnegie (2003), 'Social entrepreiternational Journal of Nonprofit and ial entrepreneur', National Centre for
Thompson, J.L. (2002), 'The world of the social entrepreneur', International Journal of Public Sector Management, 15(4/5), 412-31.

Thompson, J.L. and B. Doherty (2006), "The diverse world of social enterprise: a collection of social enterprise stories', International Journal of Social Economics, 33(5/6), 361-75.

Thompson, J.L., G. Alvy and A. Lees (2000), 'Social entrepreneurship: a new look at the people and the potential', Management Decision, 38(5), 328-38.

Tracey, P. and N. Phillips (2007), 'The distinctive challenge of educating social entrepreneurs: a postscript and rejoinder to the special issue on entrepreneurship education', Academy of Management Learning and Education, 6(2), 264 71.

Venkataraman, S. (1997), 'The distinctive domain of entrepreneurship research", in J. Katz (ed.), Advances in Entrepreneurship, Firm Emergence and Growth 3, Greenwich, CT: JAI Press, pp. 119-38.

Verstraete, T. and A. Fayolle (2004), 'Quatre paradigmes pour cerner le domaine de recherche en entrepreneuriat', paper presented at the 7 th Congrès International Francophone en Entrepreneuriat et PME, Montpellier, 27-29 October.

Wallace, S.L. (1999), 'Social entrepreneurship: the role of social purpose enterprises in facilitating community economic development', Journal of Developmental Entrepreneurship, 4(2), 153-74.

Weerawardena, J. and G. Sullivan Mort (2006), 'Investigating social entrepreneurship: a multidimensional model', Journal of World Business, 41(1), 21-35.

Young, D.R. (2001), 'Organizational identity in non-profit organizations: strategic and structural implications', Nonprofit Management \& Leadership, 12(2), $139-57$.

Zahra, S.A., E. Gedajlovic, D.O. Neubam and J.M. Shulman (2009), 'A typology of social entrepreneurs: motives, search processes and ethical challenges', Journal of Business Venturing, 24(5), 519-32. 


\section{APPENDICES}

\section{Appendix A: Which Author belongs to which School?}

In the United States, two independent streams of practice can explain the interest for social entrepreneurship. These two streams resulted in two schools of thought that investigated the nature of social entrepreneurship: the Social Innovation School of thought, on the one hand, and the Social Enterprise School of thought, on the other hand (Dees and Battle Anderson, 2006). Table 7A.1 presents a classification of the main authors of each of these two approaches.

\section{Table 7A.1 Classification of the main authors in the American streams of social entrepreneurship}

\begin{tabular}{ll}
\hline Social Innovation School & Social Enterprise School \\
\hline Alvord et al. (2004) & Alter (2004) \\
Austin et al. (2006) & Boschee (1995) \\
Bornstein (1998-2004) & Boschee and McClurg (2003) \\
Catford (1998) & Emerson and Twersky (1996) \\
Chell (2007) & Guclu et al. (2002) \\
De Leeuw (1999) & Haugh and Tracey (2004) \\
Dees (1998) & Stryjan (2006) \\
Drayton (2002) & Tracey and Philips (2007) \\
Drucker (1985) & \\
Kerlin (2006) & \\
Kramer (2005) & \\
Leadbeater (1997) & \\
Mair and Marti (2004; 2006) & \\
Mair and Noboa (2006) & \\
Peredo and McLean (2006) & \\
Roberts and Woods (2005) & \\
Robinson (2006) & \\
Schuyler (1998) & \\
Schwab (1998) & \\
Sharir and Lerner (2006) & \\
Skoll in Dearlove (2004) & \\
Smallbone et al. (2001) & \\
Sullivan Mort et al. (2003) & \\
Thompson et al. (2000) & \\
Weerawardena and Sullivan Mort (2006) & \\
Young (2001) & \\
\hline
\end{tabular}

Appendix B: The Individu

Table 7A.2 Definitions American sc

Social Imnovation School

Social entrepreneurs combin activism with professional sk visionary insights with pragm ethical fibre with tactical trus opportunities where others or buildings, unemployable peo unvalued resources. (Catforo

Social entrepreneurs play the of change agents in the social adopting a mission to create social value (not just private recognizing and relentlessly new opportunities to serve th engaging in a process of con innovation, adaptation, and acting boldly without being by resources currently at har exhibiting heightened accou to the constituencies served outcomes created. (Dees, 19 3-4)

Ashoka's social entrepreneu breaker with a powerful new combines visionary and real problem-solving creativity, strong ethical fiber, and whe possessed' by his or her visi (Drayton, in Bornstein, 199

Individuals who have a visi social change and who have resources to support their ic exhibit all the skills of succe people as well as a powerful social change. (Schuyler, 19 


\section{Appendix B: The Individual: Definitions of the Social Entrepreneur}

\section{hich School?}

treams of practice can explain the hese two streams resulted in two he nature of social entrepreneurhought, on the one hand, and the 1 the other hand (Dees and Battle classification of the main authors

wthors in the American streams of

\author{
Social Enterprise School \\ Alter (2004) \\ Boschee (1995) \\ Boschee and McClurg (2003) \\ Emerson and Twersky (1996) \\ Guclu et al. (2002) \\ Haugh and Tracey (2004) \\ Stryjan (2006) \\ Tracey and Philips (2007)
}

\section{Table 7A.2 Definitions of the 'social entrepreneur' according to the two American schools of thought}

\begin{tabular}{|c|c|}
\hline hool & 1 \\
\hline $\begin{array}{l}\text { lepreneurs combine street } \\
\text { ith professional skills, } \\
\text { ithights with pragmatism, and } \\
\text { e with tactical trust. They see } \\
\text { ies where others only see empty } \\
\text { unemployable people and }\end{array}$ & $\begin{array}{l}\text { ves who pay increased } \\
\text { et forces without losin } \\
\text { rlying mission, to } \\
\text { moral imperatives and } \\
\text { - and that balancing a } \\
\text { ul of the movement. }\end{array}$ \\
\hline $\begin{array}{l}\text { Social entrepreneurs play the role } \\
\text { of change agents in the social sector, by: } \\
\text { adopting a mission to create and sustain }\end{array}$ & $\begin{array}{l}\text { Social entrepreneurs must be able to } \\
\text { articulate a compelling social impact } \\
\text { theory and a plausible business model. } \\
\text { (Guclu et a1., 2002, in Acs and Kallas, } \\
2007: 30)\end{array}$ \\
\hline
\end{tabular}

new opportunities to serve that mission; engaging in a process of continuous innovation, adaptation, and learning; acting boldly without being limited by resources currently at hand; and exhibiting heightened accountability to the constituencies served and for the outcomes created. (Dees, 1998a: 3-4)

Ashoka's social entrepreneur is a path breaker with a powerful new idea, who combines visionary and real-world problem-solving creativity, who has a strong ethical fiber, and who is 'totally possessed' by his or her vision of change. (Drayton, in Bornstein, 1998: 37)

Individuals who have a vision for social change and who have the financial resources to support their ideas. . [who] exhibit all the skills of successful business people as well as a powerful desire for social change. (Schuyler, 1998: 1)
Individuals who combine social and commercial objectives by developing economically sustainable solutions to social problems. It requires social entrepreneurs to identify and exploit market opportunities in order to develop products and services that achieve social ends, or to generate surpluses that can be reinvested in a social project. (Tracey and Phillips, 2007: 264) 


\section{Table 7 A.2 (continued)}

\section{Social Innovation School}

Social Enterprise School

Someone who: identifies and

applies practical solutions to social problems. . .; innovates by finding a new product, service or approach. .., focuses. . . on social value creation. ..; resists being trapped by the constraints of ideology and discipline; has a vision, but also a well-thought out roadmap as to how to attain the goal. (Schwab Foundation, 1998)

Rare individuals with the ability to analyze, to envision, to communicate, to empathize, to enthuse, to advocate, to mediate, to enable and to empower a wide range of disparate individuals and organizations. (De Leeuw, 1999: 261)

People who realize where there is an opportunity to satisfy some unmet need that the state welfare system will not or cannot meet, and who gather together the necessary resources (generally people, often volunteers, money and premises) and use these to 'make a difference'. (Thompson et al., 2000: 328)

Social entrepreneurs are first driven by the social mission of creating better social value than their competitors which results in them exhibiting entrepreneurially virtuous behaviour. Secondly, they exhibit a balanced judgment, a coherent unity of purpose and action in the face of complexity. Thirdly, social entrepreneurs explore and recognize opportunities to create better social value for their clients. Finally, social entrepreneurs display innovativeness, proactiveness and risktaking propensity in their key decision making. (Sullivan Mort et al., 2003: 82)
Table 7A.2

Social Innovation S

At the Skoll Found social entrepreneur agents': the pioneer social sector. Socia have a vision of son would like to solve (Skoll, in Dearlove

Visionary, passion individuals. (Robe 49)

Social entrepreneu where some person exclusively or in so to create social val and pursue that go combination of (1) exploiting opportu value, (2) employi tolerating risk, an limitations in avai and McLean, 2006

The social entrepr a change agent to social value withor resources currently Lerner, 2006: 7)

Note: The chrono of the concept acro entrepreneurship') perspective is not $t$ aspect of the phenc 


\section{Table 7 A.2 (continued)}

\section{Social Enterprise School}

\begin{tabular}{l} 
Social Innovation School \\
\hline At the Skoll Foundation we call \\
social entrepreneurs 'society's change \\
agents': the pioneers of innovation for the \\
social sector. Social entrepreneurs usually \\
have a vision of something that they \\
would like to solve in the social sector. \\
(Skoll, in Dearlove, 2004: 52 ) \\
Visionary, passionately dedicated \\
individuals. (Roberts and Woods, 2005: \\
49 ) \\
Social entrepreneurship is exercised \\
where some person or group aims either \\
exclusively or in some prominent way \\
to create social value of some kind, \\
and pursue that goal through some \\
combination of (1) recognizing and \\
exploiting opportunities to create this \\
value, (2) employing innovation,(3) \\
tolerating risk, and (4) declining to accept \\
limitations in available resources. (Peredo \\
and McLean, 2006: 64) \\
The social entrepreneur is acting as \\
a change agent to create and sustain \\
social value without being limited to \\
resources currently at hand. (Sharir and \\
Lerner, 2006: 7)
\end{tabular}

Note: The chronological order has been chosen in order to shed light on the evolution of the concept across time. This note is valuable for Table 7A.3 (the concept of 'social entrepreneurship') and Table 7A.4 (the concept of 'social enterprise'). The European perspective is not tackled in Appendices $B$ and $C$ as it mainly focuses on the organizational aspect of the phenomenon of social entrepreneurship. 
Appendix C: The Process: Definitions of Social Entrepreneurship

Table 7A.3 Definitions of 'social entrepreneurship' according to the two American schools of thought

Social Innovation School

A vast array of economic, educational, research, welfare, social and spiritual activities engaged in by various organizations. (Leadbeater, 1997)

It combines the passion of a social mission with an image of businesslike discipline, innovation and determination. (Dees, 1998a: 1)

A process consisting in the innovative use and combination of resources to explore and exploit opportunities, that aims at catalyzing social change by catering to basic human needs in a sustainable manner. (Mair and Martí, 2004: 3)

Social entrepreneurship encompasses the notions of "construction, evaluation and pursuit of opportunities' as means for a 'social transformation' carried out by visionary, passionately dedicated individuals. (Roberts and Woods, 2005: 49)

Innovative, social value creating activity that can occur within or across the nonprofit, business, andlor publicl government sectors. (Austin et al., 2006: 1)

The innovative use of resource combinations to pursue opportunities aiming at the creation of organizations and/or practices that yield and sustain social benefits. (Mair and Noboa, 2006)

\section{Social Enterprise School}

Social entrepreneurship is viewed as a category of entrepreneurship that primarily (a) is engaged in by collective actors, and (b) involves, in a central role in the undertaking's resource mix, socially embedded resources [. . .] and their conversion into (market-) convertible resources, and vice-versa. (Stryjan, 2006: 35)
Social Innovation Sc

- A behavioural ph expressed in a NF context aimed at value through the perceived opportu

- Social entreprene multidimensional deeply rooted in : social mission, its sustainability and and shaped by th dynamies. Oppor embedded in thes

- Social entreprene achieve social val requires the displ proactiveness and behaviour.

- Social entreprene regard to risk is 1 by their primary a sustainable orgs does not support social entreprene lack of initial res options.

Finally, social entro remain competitive social mission. (We Sullivan Mort, 200 


\section{Social Entrepreneurship}

reneurship' according to the two $h t$

\section{Social Enterprise School}

ocial entrepreneurship is viewed as category of entrepreneurship that rimarily (a) is engaged in by collective ctors, and (b) involves, in a central ole in the undertaking's resource nix, socially embedded resources [. . . ] and their conversion into (market-) onvertible resources, and vice-versa. Stryjan, 2006: 35)
Table 7A.3 (continued)

Social Innovation School Social Enterprise School

- A behavioural phenomenon expressed in a NFP organization context aimed at delivering social value through the exploitation of perceived opportunities.

- Social entrepreneurship is a bounded multidimensional construct that is deeply rooted in an organization's social mission, its drive for sustainability and highly influenced and shaped by the environmental dynamics. Opportunity recognition is embedded in these three dimensions.

- Social entrepreneurship strives to achieve social value creation and this requires the display of innovativeness, proactiveness and risk management behaviour.

- Social entrepreneurs' behaviour in regard to risk is highly constrained by their primary objective of building a sustainable organization and hence does not support Dees' view that social entrepreneurs do not allow the lack of initial resources to limit their options.

Finally, social entrepreneurs can indeed remain competitive whilst fulfilling their social mission. (Weerawardena and Sullivan Mort, 2006: 22, 32) 
Appendix D: The Organization: Definitions of the Social Enterprise

\section{Table 7A.4 Definitions of the 'social enterprise' according to the different schools of thought}

Social Innovation School
Enterprises set up for
a social purpose but
operating as businesses
and in the voluntary
or nonprofit sector.
However, according to
him, the main world of the
social entrepreneur is the
voluntary (NFP) sector.
(Thompson, 2002)

Social enterprises enact hybrid non-profit and forprofit activities. (Dart, 2004: 415)

\section{$[\ldots]$ a range of} organizations that trade for a social purpose. They adopt one of a variety of different legal formats but have in common the principles of pursuing business-led solutions to achieve social aims, and the reinvestment of surplus for community benefit. Their objectives focus on socially desired, non financial goals and their outcomes are the non financial measures of the implied demand for and supply of services. (Haugh, 2005: 3)

Social Enterprise School European Conceptual Approaches
Organizations positioned

in two different organizational fields - each necessitating different internal organizational technologies - to elucidate the structural tensions that can emerge inside these new hybrid models. (Cooney, 2006: 143)
Organizations with an explicit aim to benefit the community, initiated by a group of citizens and in which the material interest of capital investors is and Nyssens, 2006)

\section{An independent} organization that has social and economic objectives which aims to fill a social role as well as reach financial durability through commerce. (DTI, 2001) subject to limits. (Defourney
Table $7 A .4$ (continued)

Social Innovation School

Non-profit, for-profit or cross-sector Social Entrepreneurial Ventures are social because they aim to address a problem the private sector has not adequately addressed; they are entrepreneurial because their founders have qualities identified with entrepreneurs.

(Dorado, 2006: 327)

Social enterprises have a social purpose; assets and wealth are used to create com munity benefit; they pursue this with trade in a market place; profits and surpluses ar not distributed to shareholders; 'members' or employees have some role in decision making and/or governance; the enterprise is seen as accountable to both its members and a wider community; there is a double- or triplebottom-line paradigm: the most effective social enterprises demonstrate healthy financial and social returns. (Thompson and Doherty, 2006: 362)

Social entrepreneurial organizations must clearly address value positioning strategies, and take a

proactive posture as well as providing superior service maximizing social value creation. (Weerawardena and Sullivan Mort, 2006: 2 


\section{f the Social Enterprise}

'ise' according to the different

European Conceptual Approaches

ed Organizations with an explicit aim to benefit the community, initiated by a group of citizens and in which the material interest of capital investors is

late subject to limits. (Defourney and Nyssens, 2006)

An independent organization that has social and economic objectives which aims to fill a social role as well as reach financial durability through commerce. (DTI, 2001)
Table 7 A.4 (continued)

Social Innovation School Social Enterprise School European Conceptual Approaches

Non-profit, for-profit

or cross-sector Social

Entrepreneurial Ventures

are social because they

aim to address a problem

the private sector has not

adequately addressed;

they are entrepreneurial

because their founders

have qualities identified

with entrepreneurs.

(Dorado, 2006: 327)

Social enterprises have a social purpose; assets and wealth are used to create community benefit; they pursue this with trade in a market place; profits and surpluses are not distributed to shareholders; 'members' or employees have some role in decision making and/or governance; the enterprise is seen as accountable to both its member's and a wider community; there is a double- or triplebottom-line paradigm: the most effective social enterprises demonstrate healthy financial and social returns. (Thompson and Doherty, 2006:362)

Social entrepreneurial organizations must clearly address value positioning strategies, and take a proactive posture as well as providing superior service maximizing social value creation. (Weerawardena and Sullivan Mort, 2006: 21) 